\title{
Dekontruksi Pranata Erturang Pada Perkawinan Semarga (Studi Kasus Masyarakat Karo di Berastagi)
}

\author{
NOVRASILOFA S. \\ Program Pascasarjana Kajian Budaya Universitas Sebelas Maret \\ novrasilofa@gmail.com
}

\begin{abstract}
Abstrak
Modernisasi dan globalisasi telah menyentuk seluruh aspek kehidupan sosial budaya masyarakat termasuk masyarakat Suku Karo di Berastagi.Salah satu budaya karo yang mengalami perubahan adalah pranata erturang.Pranata ini dipahami oleh kaum muda sebagai pranata yang kuno dan cenderung mengikat, sehingga saat ini kaum muda mengaplikasikan pranata tersebut sesuai dengan keinginannya yang dianggap sesuai dengan keadaan sekarang. Akibatnya secara tidak langsung kaum muda telah mendekonstruksi makna dari erturang tersebut sesuai dengan kapasitasnya saat ini.Akibatnya pranata tersebut sebagai sebuah struktur telah mengalami perubahan makna dan konsep.Perubahan ini juga akhirnya memunculkan perkawinan yang dianggap menyimpang bagi Suku Karo. Perkawinan semarga ini tentunya tidak dapat diterima oleh berbagai kalangan, oleh karena itu pelakunya berusaha untuk mensahkan hubungannya dengan berbagai cara.

Penelitian ini dilakukan dengan menggunakan pendekatan etnografi, selain itu untuk mendapatkan data dilakukan observasi, wawancara, serta studi dokumen tertulis. Penelitian ini bertujuan untuk mengungkap bagaimana kaum muda memahami pranata erturang saat ini dan bagaimana proses serta implikasi perkawinan semarga bagi para pelakunya. Penelitian ini menggunakan teori dekonstruksi dan strukturasi untuk membantu menjabarkan haasil penelitian.
\end{abstract}

Kata Kunci : Erturang-Generasi Muda-Perkawinan Semarga-Dekonstruksi-Karo

\section{Abstract}

Modernization and globalization has shaped all aspects of social and cultural life of society including Karo tribe community in Berastagi.Salah a karo culture that undergoes change is pranata erturang.Pranata is understood by young people as ancient institutions and tend to bind, so that today young people apply the rules Is in accordance with the wishes that are considered in accordance with the current situation. As a result indirectly young people have deconstructed the meaning of erturang is in accordance with the current capacity. As a result the structure as a structure has undergone a change of meaning and concepts. This change also ultimately led to marriage is considered Deviate to the Karo Tribe. This marriage of marriage is certainly unacceptable to the various circles, therefore the culprit seeks to validate his relationship in various ways.

This research was conducted by using ethnography approach, in addition to get the data done by observation, interview, and written document study. This study aims to reveal how young people understand the current institutions and how the processes and implications of marriage as well as the perpetrators. This study uses the theory of deconstruction and structure to help elucidate the results of research.

Keywords : Erturang-Young Generation-Marriage Semi-Deconstruction-Karo 


\section{PENDAHULUAN}

Suku Karo mengenal perkawinan semarga yang merupakan perkawinan terlarang dalam suku tersebut. Idealnya perkawinan di Suku Karo menganut sistem eksogami, artinya harus menikah atau mendapat jodoh di luar marganya (Darwan, 2008:71). Perkawinan Karo dapat berlangsung dengan terlebih dahulu melihat marga dan beru dari pasangan yang ingin menikah. Secara sosiologis perkawinan bagi masyarakat Karo adalah untuk mendapat pengakuan dari kerabat dan masyarakat sekitar tempat kejadian dimana upacara perkawinan berlangsung (Bangun, 1986:35).Laki-laki atau perempuan yang seketurunan (semarga) sama sekali tidak dibenarkan untuk melangsungkan perkawinan. Laki-laki yang memiliki marga yang sama dengan seorang perempuan akan saling menyebut turang. Turang merupakan panggilan untuk orang yang berlainan jenis dan memiliki marga yang sama namun memiliki umur yang sama. Mereka yang berturang (erturang)dilarang untuk menikah karena dianggap masih memiliki hubungan darah. Namun ada beberapa kelompok masyarakat yang tidak mengindahkan adat yang berlaku dan melangsungkan pernikahan semarga (Bangun, 1986:38).

Perkawinan semarga adalah suatu penyimpangan dalam masyarakat Karo berdasarkan adat yang berlaku di tengah-tengah masyarakat. Penyimpangan merupakan perilaku yang oleh sejumlah besar orang dianggap sebagai hal yang tercela dan di luar batas toleransi (Sunarto, 2000:182). Perkawinan semarga (turang) dianggap sangat menyalahi dan melanggar adat, dan para pelanggarnya akan mendapat hukuman dari masyarakat serta adat Suku tersebut. Menurut kepercayaan masyarakat jaman dahulu, pasangan yang melakukan pelanggaran akan dihukum berat dengan cara diusir dari desa mereka atau bahkan dibunuh. Pelaku perkawinan tersebut akan dikucilkan dari kekerabatan. Pengusiran dan pengucilan ini merupakan jalan satu-satunya bagi pelaku pernikahan semarga (Bangun, 1986:39). Pengusiran ini biasanya diikuti oleh desa lain (masih di daerah Karo) yang tidak memperbolehkan mereka tinggal di desa tersebut. Selain itu, mereka tidak akan mendapat restu dari keluarga dan tidak akan diakui sebagai anggota keluarga. Hal ini dianggap menjadi aib dari keluarga besar yang harus ditanggung dalam kehidupan sosial masyarakatnya. Agar keluarga besar tidak mendapat gunjingan, pasangan tersebut akhirnya dibuang ke daerah pengasingan (Desa Sunggal).

Suku Karo tidak menyetujui adanya perkawinan semarga karena dianggap dapat mengundang bahaya bagi keluarga tersebut.Selain itu perkawinan semarga sangat memalukan karena pasangan tersebut dianggap masih ada hubungan darah (Sitepu, 1996:63). Orang Karo menganggap pasangan yang melakukan perkawinan semarga atau turang merupakan satu keturunan. Menurut kepercayaan Karo, mereka merupakan keturunan dari kakek dan nenek yang sama dan dianggap sedarah sehingga dilarang untuk menikah. Jika pernikahan semarga tersebut terjadi, anak yang dilahirkan akan memiliki marga dan beru yang sama dan otomatis tidak dapat diterima oleh masyarakat Karo.

Sekarang ini banyak kalangan muda yang menikah dengan turangnya.Pelaku pernikahan semarga pun banyak yang hidup berdampingan di wilayah Berastagi. Mereka dapat beraktivitas seperti halnya masyarakat yang menikah ideal di sana. Hal ini menunjukkan bahwa sakralitas dalam suatu tradisi lambat laun semakin menurun.Pelaku tetap menerima gunjingan dari masyarakat, namun pelaku mendapat ruang di masyarakat saat ini.Masa sekarang ini kebudayaan begerak bersamaan dengan modernisasi.Geertz mengatakan bahwa tidak hanya pikiran manusia yang berubah bentuk menjadi modern secara hakiki, tetapi juga evolusi kebudayaan ikut serta memberikan makna pada perubahan yang ada (Geertz, 1992:76).Narwoko dalam bukunya juga mengatakan bahwa semua orang bersepakat bahwa kehidupan sosial tidaklah statis, melainkan selalu berubah secara dinamis (Narwoko, 2011:261-262).Hakekatnya modernisasi memberikan pengaruh positif bagi perkembangan suatu negara, namun modernisasi juga dapat 
memberi pengaruh negatif bagi kebudayaan jika masyarakatnya tidak mampu menjaga kebudayaannya.

Saat ini perkembangan jaman ternyata ikut mempengaruhi pergaulan generasi muda di Tanah Karo.Menurut pengamatan dilapangan, konsep erturang sudah disalah artikan oleh sebagaian besar kalangan muda.Dahulu tiap-tiap orang tidak diijinkan berada di dalam satu rumah dengan turangnya, selain itu mereka dilarang berjalan bersama turang apalagi saling berboncengan (pada jaman dahulu menggunakan sepeda).Faktanya, pranata erturang mulai memudar di kalangan anak muda sekarang. Sakralitas dengan turangnya kemudian mulai dilanggar, dan secara otomatis definisi mereka terhadap turang akan mengalami perubahan dibanding dengan konsep erturang yang dipahami oleh orang tua.

Dalam beberapa kasus, pernikahan semarga terjadi tidak hanya karena kurangnya kesadaran erturang tetapi ada beberapa anak muda yang memiliki kecemburuan sosial dengan margaKaro lain. Kecemburuan yang dimaksud adalah saat beberapa marga mendapat batasan dalam memilih pasangan, ternyata marga lain dalam suku Karo ternyata dapat menikahi pasangan semarganya sendiri. Akibatnya kaum muda ini merasa wajar untuk melakukan hal yang sama dengan marga yang mendapat hak istimewa tersebut. Kasus lain yang terjadi adalah pada saat berkenalan, salah satu dari mereka membohongi pasangan dengan mengubah marganya. Hal ini sangat menjadi masalah ketika seseorang berani berbohong tentang marganya, dapat dikatakan bahwa telah terjadi dekonstruksi terhadap marga dan turang dalam kehidupan orang tersebut.

Penelitian ini menjadi penting mengingat perkawinan semarga merupakan suatu bentuk fenomena budaya. Penelitian ini dilakukan karena pemahaman generasi muda terhadap turang perlu dikaji sehingga terlihat bagaimana kaum muda mengaplikasikan pada kehidupannya. Penelitian ini mencoba menjabarkan bagaimana konsep erturang dipahami oleh generasi muda, mengapa sebagian genera- si muda Karo melakukan perkawinan semarga, dan bagaimana implikasi perkawinan semarga terhadap kehidupan sosial pelakunya.

\section{METODE}

Lokasi penelitian berada di Berastagi, Kecamatan Berastagi, Kabupaten Karo, Sumatera Utara. Berastagi merupakan Ibu Kota Kecamatan. Strategi yang digunakan dalam penelitian ini adalah studi kasus tunggal terpancang atau embedded case study. Penelitian ini terfokus pada sasaran yang terpusat pada satu karakteristik saja yaitu di Berastagi yang merupakan lingkungan masyarakat Karo. Pengumpulan data dilakuakan ddengan cara observasi, wawancara, dan studi dokumen tertulis. Bentuk penelitian ini menggunakan bentuk deskriptif kualitatif. Sutopo (2006:179) mengatakan bahwa penelitian dengan bentuk deskriptif kualitatif merupakan bentuk penelitian yang mengarah pada pendeskripsian secara rinci dan mendalam baik kondisi maupun proses dan juga hubungan saling keterkaitan mengenai hal-hal pokok yang ditemukan pada sasaran penelitian. Metode deskriptif analisis digunakan untuk mendeskripsikan atau menggambarkan data yang telah terkumpul sebagaimana adanya (Sugiyono, 2007:14). Penelitian kualitatif bermaksud untuk memahami fenomena tentang apa yang dialami oleh subjek penelitian misalnya perilaku, persepsi, motivasi, tindakan, dan lain-lain (Moleong, 2007:6).

Pendekatan yang digunakan pada masalah ini adalah pendekatan etnografi. Pendekatan etnografi menurut Charles Winick adalah pendekatan tentang kebudayaan tertentu yang bersifat deskriptif (Tarwodjo, 1994:15). Tiga ciri etnografi adalah paparan etnografi bersifat interpretatif, kedua yang interpretatif adalah aliran perbincangan sosial, dan ketiga menafsirkan antara lain mencoba menyelamatkan apa yang "dikatakan" dari perbincangan tersebut (Geertz, 1992:25). Pendekatan ini dipakai karena etnografi sendiri berbasis pada fenomenologi, dimana pada masalah ini yang di ungkap adalah fenomena yang terjadi pada sebagian generasi muda Karo yang berani melakukan 
pemberontakan terhadap adat dengan mulai tidak menganggap penting marga dalam mencari pasangan hidup.Pendekatan ini digunakan untuk melihat bagaimana permasalahan yang dihadapi oleh kelompok pelaku akibat perkawinan semarga tersebut di lapangan. Konsep penggunaan marga sendiri sebenarnya belum terkena dampak pengaruh asing, hanya saja pengaruh modernisasi di kalangan anak muda mengakibatkan mereka tidak menghargai kebudayaan yang sudah lekat di masyarakat sejak lama. Dalam menganalisa permasalahan, digunakan teori dekonstruksi dan strukturasi untuk mencar makna lain dan melihat kaitan adat dengan masyarakat Suku Karo di Berastagi.

\section{HASIL DAN PEMBAHASAN}

Subjek penelitian adalah beberapa kaum muda dengan rentang usia 18-24 tahun dan belum menikah juga para pelaku perkawinan semarga yang sebelumnya merupakan jemaat gereja GBKP. Kaum muda di berastagi masih mengetahui proses ertutur yang benar adalah dengan memperkenalkan marga terlebih dahulu kemudian bisa dilanjutkan dengan menanyakan bere-bere. Beberapa kaum muda masih menganggap bahwa memposisikan diri sejak awal itu penting untuk menentukan siapa dia dalam proses perkenaalan tersebut, apakah turang atau impal dari lawan bicaranya. Akan tetapi untuk saat ini mereka merasa bahwa mereka juga mulai merubah caranya dalam berkenalan dengan terlebih dahulu menanyakan nama lalu dilanjutkan dengan menanyakan marga kemudian bere-bere. Menurut mereka untuk saat ini mereka harus lebih realistis. Apalagi sekarang mereka berpendapat bahwa perempuan jaman sekarang semakin menarik (cantik), sehingga mereka merasa wajar jika dalam proses perkenalan yang lebih dahulu ditanyakan adalah nama perempuan tersebut.

Dari observasi diketahui bahwa proses ertutur atau berkenalan sudah mengalami perubahan. Etika dalam proses ertutur saat ini sudah mengalami banyak perubahan. Larangan kedekatan yang dibuat sejak dulu, oleh kaum muda mulai dilupakan hingga pada akhirnya terjadilah kedekatan yang tidak bisa dip- isahkan dan berujung pada pernikahan semarga. Erturang menurut pemahaman kaum muda sekarang sudah tidak layak diaplikasikan seperti masa sebelumnya. Apabila konsep lama masih diterapkan, itu tidak lagi disebut dengan turang, namun lebih cocok disebut dengan rebu. Rebu dalam Suku Karo adalah tata krama dimana antara kedua belah pihak dilarang (tabu) untuk berbicara secara langsung tetapi harus melalui perantara pihak ketiga baik itu dari benda hidup maupun benda mati. Sehingga pemahaman dan aplikasi tindakan terhadap turang untuk saat ini sudah tidak bisa dilakukan seperti jaman sebelumnya. Jika dilihat dari pernyataan kaum muda, dapat dikatakan bahwa sebagian besar kaum muda tidak menutup kemungkinan jika ternyata mereka menyukai turangnya.

Berdasarkan pendapat para informan dapat dikatakan bahwa kaum muda Karo di Berastagi dapat digolongkan sebagai generasi yang masih paham betul dengan konsep erturang. Namun kenyataannya sekarang ini, konsep erturang yang selama ini digunakan sudah tidak dapat diaplikasikan pada generasi sekarang. Hal ini terjadi karena generasi sekarang menganggap konsep erturang yang selama ini ada di Suku Karo tergolong kaku dan mengekang mereka dalam berinteraksi dengan turangnya. Untuk itu mereka melakukan terobosan baru dengan menjalin komunikasi yang intens dengan turangnya namun tetap memberi batasan sehingga tidak terjadi hal-hal yang tidak diinginkan yaitu saling suka dengan turangnya.

Dengan demikian dapat ditarik kesimpulan bahwa caraertutur atau berkenalan pada kaum muda dan bagaimana turang atau erturang diaplikasikan oleh kaum muda itu telah mengalami perubahan yang cukup besar. Persepsi kaum muda yang mendahulukan fisik saat berkenalan menjadi suatu bukti bahwa marga hampir kehilangan eksistensinya dalam proses tersebut. Dalam beberapa kasus, ada kaum muda yang menganggap hubungan semarga itu adalah hubungan yang tidak perlu dipermasalahkan oleh orang lain karena hal itu menyangkut tentang pilihan hidupnya sendiri. 
Namun dalam kasus lain masih banyak kaum muda yang meskipun mereka mementingkan fisik sebelum ertutur, tetapi mereka tetap memberi batasan jika orang yang diajak berkenalan adalah turangnya. Dalam proses mengaplikasikan proses erturang saat ini juga ternyata mengalami perubahan. Jika dahulu erturang memiliki batasan-batasan yang cukup banyak, saat ini generasi muda menganggap bahwa batasan itu sudah tidak relevan jika tetap diaplikasikan dalam kehidupan sekarang. Batasan tersebut dianggap sebagai hal yang mengikat sehingga bagi kaum muda batasan tersebut meembuat konteks erturang menjadi kaku. Sehingga pada prosesnya, kaum muda Karo di Berastagi lebih memilih meninggalkan gayaerturang sebelumnya dengan membuat inovasi baru namun tetap pada batasan sehingga mengurangi terjadinya kenyamanan berlebih yang mengacu pada terjadinya perkawinan semarga.

Ada 2 faktor yang melatarbelakangi terjadinya perkawinan semarga yaitu faktor internal dan faktor eksternal. Faktor internal berasal dari hal-hal dalam diri pelaku yang mengakibatkan terjadinya perkawinan semarga, sedangkan faktor eksternal berkaitan dengan hal-hal yang berada di luar diri pelaku tersebut. Faktor internal yang melatarbelakangi para kaum muda melakukan perkawinan semarga adalah karena keinginan dari dirinya sendiri. Faktor internal yang melatarbelakangi terjadinya perkawinan semarga adalah karena adanya perasaan saling menyayangi antara keduanya. Selain itu keterikatan antar keduanya juga sangat mempengaruhi proses perkawinan ini. Intensitas informan dalam berkomunikasi, saling bertukar fikiran, dan membahas masalah dengan turangnya juga menjadi pemicu rasa nyaman. Di samping itu perasaan yang timbul dengan turang sangat kuat. Perasaan cinta terhadap turang jauh lebih kuat di banding dengan impal. Akibatnya meskipun hubungan seluruh informan mendapat larangan dari sejumlah pihak, namun karena perasaan nyaman yang kuat membuat mereka rela meninggalkan keluarga demi menikah dengan turangnya tersebut. Oleh karena itu kedekatan tersebut harus diberi jarak agar tidak berujung pada perkawinan semarga.

Faktor eksternal yang melatarbelakangi terjadinya perkawinan semarga pada generasi muda Karo di Berastagi adalah penggunaan media sosial yang salah.Faktor eksternal lain yang menjadi pemicu perkawinan semarga adalah adanya keistimewaan yang dimiliki oleh beberapa marga di Suku Karo sehingga menimbulkan perasaan cemburu.

Suku Karo mengenal konsep marga. Sebagian orang Karo pernah mengatakan bahwa marga adalah "meherga" yang artinya mahal. Marga membentuk kepribadian orang Karo tersebut menjadi sangat mahal, baik ditinjau dari sikap hidupnya maupun dari dasar hubungan kekeluargaannya. Fungsi marga sendiri adalah sebagai suatu ikatan yang tidak boleh terlepas dari kepribadian orang Karo (Tarigan, 2011:42). Sebelum melakukan perkenalan, kewajiban seorang Karo adalah memanggil lawan bicaranya dengan sebutan turang bukan impal. Hal ini menjadi sebuah bentuk kesopanan dan rasa hormat dari seseorang kepada lawan bicaranya. Untuk mengetahui seseorang menjadi impal atau turang, maka diperlukan proses perkenalan yang disebut dengan ertutur. Sejalan dengan apa yang diungkapkan oleh Barus (1993:5-6) tutur atau ertutur adalah proses perkenalan guna menjalin hubungan antara seseorang dengan yang lain agar saling mengenal dan saling tahu garis/jalur tutur. Prinsip ertutur dalam masyarakat Karo haruslah menunjukkan kerendahan hati. Artinya dalam bertutur itu dicarikan jalan sedemikian rupa agar kita itu mengikuti posisi. Tujuan dari ertutur adalah untuk mengetahui tinggi rendahnya derajat dalam pergaulan adat dan dapat diketahui asal turunannya (Tamboen, 1952:69).

konsep erturang dan aktor saling berintegrasi. Yang menjadi perhatian tidak hanya pada erturang tersebut sebagai sebuah produk budaya, tidak juga hanya melihat pengalaman aktor dalam kehidupan sosial. Tetapi perubahan yang terjadi juga harus dilihat dari praktik sosial yang terus menerus terjadi yang melintasi ruang dan waktu sebagaimana yang di kemukakan oleh Ritzel (2004:507) berikut. 
Giddens beranggapan bahwa struktur dan agen saling berkesinambungan satu sama lain dan memiliki peranan masing-masing dalam praktik sosial. Giddens menolak kedua elemen tersebut sebagai dualisme, dimana salah satu dari elemen tersebut mendominasi dari adanya praktik sosial. Giddens menyatakan bahwa kita harus memulai dari praktik (interaksi) sosial yang berulangulang.

Dari penjelasan yang diperoleh di lapangan memperlihatkan bahwa proses ertutur pada kaum muda Karo sekarang sudah tidak sesuai dengan cara ertutur yang selama ini digunakan oleh Masyarakat Karo. Jika dahulu marga atau beru menjadi hal pertama yang ditanyakan, saat ini kaum muda lebih dahulu menanyakan nama dari lawan bicaranya. Kaum muda juga lebih memilih untuk mengutamakan paras lawan jenisnya dibandingkan menanyakan marga terlebih dahulu. Sehingga ini dapat menjadi salah satu alasan seseorang menyukai semarganya. Namun ternyata tidak semua kaum muda melepaskan begitu saja peran marga dalam proses perkenalan dan pendekatan dengan lawan jenisnya. Sebagain dari kaum muda di Berastagi mengatakan jika paras tetap menjadi yang utama saat ini, namun jika terbukti lawan bicaranya adalah turangnya dia merasa mampu dan harus memberikan batasan sehingga dia dapat mengurangi terjadinya hal yang dapat menyusahkannya kedepan. Ini menjadi bukti bahwa tidak semua kaum muda merasa marga menjadi bagian yang kurang penting untuk saat sekarang ini.

Konteks erturang pada saat ini ternyata memiliki pengertian dan praktek yang berbeda-beda dari tiap-tiap aktornya. Interaksi setiap individu yang berbeda-beda terhadap turangnya pada akhirnya memunculkan suatu diferensiasi pada pemahaman dan pemaknaan konteks erturang bagi pemuda di Berastagi. Akibatnya erturang kini mengalami perubahan makna bagi setiap orang. Pemaknaan ulang tersebut akan menciptakan suatu konstruksi baru bagi sebuah teks termasuk teks budaya. Pemaknaan ulang atas teks atau erturang ini akan mengungkap makna-makna yang tertunda dari teks itu sendiri (Pitana, 2010:23).

Kenyataan saat ini, erturang sebagai se- buah struktur dianggap terlalu pasif jika mengikuti pemahaman sebelumnya. Kepasifan dalam erturang sangat berseberangan dengan perilaku kaum muda saat ini. Oleh karena itu mereka menolak jika prinsip berturang masih se „kuno" pemahaman sebelumnya. Kaum muda sebagai agen yang aktif memiliki pemahaman yang berbeda-beda terkait apa dan bagaimana erturang saat ini. Hal ini sejalan dengan pemahaman Giddens. Bagi Giddens saat agen memiliki kuasa untuk memproduksi tindakan, itu berarti agen saat itu juga melakukan reproduksi dalam konteks menjalani kehidupan sosial sehari-hari.

Pranata erturang pada Suku Karo merupakan suatu bentuk hasil ciptaan masyarakat Karo yang dibuat sebagai sebuah lembaga sosial yang berfungsi untuk menjaga dan mewujudkan kedamaian serta ketertiban bagi tiap-tiap masyarakatnya. Praktek erturang dalam masyarakat Suku Karo memiliki norma yang sudah ada sejak lama. Sehingga jika salah seorang kelompoknya melakukan pelanggaran, si pelaku akan mendapat hukuman dari masyarakat dan adat tersebut.

Sebagai kota Kecamatan, Berastagi dapat dengan mudah menjadi sasaran modernitas mendahului daerah-daerah lain di sekitarnya. Kota merupakan arena empuk bagi perluasan dominasi modernitas untuk menancapkan kuku-kuku modernitasnya.Sementara ekonomi uang menjadi alat pengendali dan penyebaran modernitas dan perluasannya. Kota adalah tempat modernitas terkonsentrasi atau di intensifkan, sementara ekonomi uang melibatkan penyebaran modernitas dan perluasannya (Ritzer, 2012:933).Penggunaan hp yang berlebihan dan tidak terkendali pada kaum muda menjadikan telepon genggam itu sebagai suatu barang yang tidak bisa lepas dari kaum muda saat ini. Ketergantungan tersebut juga berimbas pada cara penggunaan telepon genggam yang salah. Modernisasi yang dibawa oleh teknologi tersebut di kota Berastagi pada akhirnya melunturkan pemahaman kaum muda tentang pentingnya ertutur yang benar menurut adat Karo.

Transformasi struktur dalam suatu ba- 
gian sistem ini pada akhirnya akan menimbulkan ketegangan-ketegangan dan pertentangan, akibatnya membutuhkan proses penyesuaian dalam sektor-sektor lain. Dengan kata lain mereka mengalami akibat proses- proses itu, yang mana menimbulkan problem khusus dalam rangka penyesuaian. Dalam transformasi itu tingkah laku sosial melepaskan diri dari kebiasaan kultural, sehingga terjadilah modifikasi dilapangan adat kebiasaan, kepercayaankepercayaan (Simandjuntak, 1984:5-6). Dalam kehidupan kaum muda di Berastagi, memang sudah terjadi perubahan pemahaman terhadap pranata erturang. Hal ini jelas menjadi suatu permasalahan bagi pihak yang pro dan kontra akan perubahan tersebut. Sehingga dengan perbedaan pendapat tersebut muncullah pemahaman yang berbeda-beda dari tiap-tiap kaum muda di Berastagi.

Erturang sebagai sebuah teks ternyata telah mengalami dekonstruksi oleh kelompok masyarakat terutama kaum muda dalam penelitian ini.Sebuah teks selalu memiliki wajah ganda, bahkan dalam waktu dan kondisi tertentu sebuah kontruksi mungkin bermakna lebih (Weber, 2013:135). Makna tersebut sering kali tidak terfikirkan karena mungkin merupakan makna sekunder yang tidak dikehendaki. Akan tetapi keberadaan makna itu sudah membuktikan bahwa pemahaman kita terhadap teks tidak pernah tunggal dan menyimpan potensi penafsiran baru yang sering kali tidak terduga (Al-fayyadl, 2009:78). Sama halnya dengan yang dikatakan oleh Ratna (2010:247) bahwa dekonstruksi sudah ada di depan kita, sehingga tidak mungkin untuk menolaknya.Erturang sebagai sebuah pranata dalam kehidupan berbudaya di Berastagi telah mengalami pemaknaan dari berbagai pihak khususnya kaum muda lewat interaksi yang beragam dari tiap individu.

Dilihat dari pemahaman informan pada bab sebelumnya, saat ini konsep erturang sudah tidak dapat disesuaikan dengan cara yang lama dan setiap orang tidak perlu bersikap sangat kaku dengan turangnya. Hal ini terjadi mengingat saat ini pola pertemanan baik di lingkungan rumah, sekolah dan tempat lainnya sudah mengalami perubahan. Bagi kaum muda di Berastagi, untuk jaman sekarang sudah sangat wajar bila si erturang duduk bersebelahan, berada dalam satu ruangan, dan sebagainya. Ini menjadi bukti bahwa pengaruh perkembangan jaman menjadi salah satu faktor perubahan pemahaman anak muda terhadap budaya di lingkungannya. Tidak jarang kaum muda menganggap hidup berbudaya berarti hidup dalam kekolotan bahkan dianggap sebagai suatu yang kuno. Ini terjadi karena mereka dihadapkan dengan teknologi yang mendukung dan kemudian dikuasai oleh teknologi yang ada di sekitarnya. Kemunculan teknologi yang menghegemoni kaum muda menjadikan mereka menjadi pribadi yang individualis. Oleh karenanya bentuk erturang saat ini jelas mengalami perubahan.

Jika dahulu masyarakat masih sangat menjunjung tinggi nilai adat, sekarang kaum muda lebih dikuasai oleh idiologinya masingmasing. Dahulu perlakuan seseorang dengan turangnya tidak sebebas saat ini, dengan kata lain setiap orang diwajibkan untuk menghargai turangnya. Bentuk perlakuan dengan turang sangat berbeda dibanding dengan impal. Seseorang dengan turangnya dilarang berada dalam satu rumah atau ruangan, selain itu mereka juga dilarang jalan berdua, duduk bersebelahan, hingga dilarang berboncengan. Ini terjadi karena orang tua jaman dahulu merasa takut akan terjadi sesuatu yang tidak diinginkan. Orang tua khawatir apabila anaknya terlalu dekat dengan turangnya, maka akan timbul perasaan nyaman yang sangat susah untuk dipisahkan. Orang Karo memiliki kepercayaan bahwa mereka akan lebih mudah untuk dekat dan merasa nyaman dengan turangnya dibanding dengan impal karena memiliki "darah" yang sama. Oleh karena itu jika perasaan nyaman tersebut tidak dapat dibatasi oleh kaum muda, maka akan berakibat pada terjadinya perkawinan semarga.

Norma-norma yang ada pada adat ertutur sebenarnya adalah agar kaum muda belajar etika atau tata krama pergaulan hidup dengan sesamanya.Hal ini sejalan dengan ungkapan Prinst (2008:65) yang mengatakan adat dan kebiasaan yang diwariskan dari generasi ke 
generasi secara turun temurun di kalangan Suku Karo penting demi menjaga kearifan yang merupakan hukum atau budaya yang hidup pada masyarakat tersebut. Saat ini setiap kaum muda di Berastagi dapat dengan bebas memahami konsep erturang. Hal ini didukung dengan ideologi tiap kaum muda yang berbeda-beda. Turang atau erturang tidak lagi dipandang sebagai hal yang sangat tabu untuk dijelaskan dan diekspresikan. Secara keseluruhan, kaum muda di Berastagi merasa bahwa perilaku yang ditunjukkan kepada turang tidak harus diekspresikan seperti halnya jaman dahulu. Bagi mereka, tindakan fisik seperti berjalan bersama, duduk bersebelahan, bahkan berboncengan menjadi hal yang wajar untuk saat sekarang.

Untuk saat ini permasalahan terkait kedekatan dengan turang dianggap sebagai hal yang wajar dan justru mengarah ke arah yang lebih baik. Perempuan dengan turangnya dapat lebih leluasa bercerita mengenai apapun. Lakilaki pun memiliki rasa tanggung jawab untuk menjaga turangnya. Menjaga dalam artian memberi solusi terhadap apa yang diceritakan turangnya si perempuan. Tindakan yang demikian dilakukan antara sesama turang dianggap menjadi suatu tindakan yang baik mengingat dahulu saling berturang tidak bisa saling berkomunikasi dengan intens.

Perilaku kaum muda Berastagi yang menganggap konteks erturang merupakan bentuk kedekatan yang tidak perlu di atur oleh adat merupakan salah satu bentuk yang sengaja atau tidak telah diubah oleh kaum muda. Konteks erturang sebagai warisan tradisi yang kaku kemudian oleh kaum muda dirubah menjadi tradisi yang memiliki kebebasan. Konteks erturang yang sebelumnya dianggap sebagai konteks yang kuno dan kaku, sehingga tidak layak untuk digunakan untuk saat yang sekarang. Fakta ini terbukti dengan semakin banyaknya kaum muda yang terjerumus pada perkawinan semarga di Berastagi. Perbedaan pandangan baik dari kaum muda maupun orang tua Karo pada akhirnya menimbulkan perdebatan. Orang tua menganggap kedekatan tersebut tidak layak untuk dilakukan mengingat sejauh apapun persaudaraan, jika memili- ki marga yang sama maka mereka tetaplah satu darah.

Pemahaman yang berbeda dari dua golongan tersebut menyimpulkan bahwa makna dari turang atau erturang tersebut di pahami oleh tiap golongan berdasarkan konteksnya. Sejalan dengan pernyataan Cavallaro (2004:20-32) yang mengatakan bahwa makna adalah produk dari situasi-situasi yang terkait serta dari suatu perbedaan tanda yang berkaitan dengan tanda-tanda lain. Oleh karena itu, makna dapat dipahami hanya dalam konteksnya.Hal ini sesuai dengan pernyataan Pitana (2010:152) yang mengatakan bahwa dalam penggunaan gagasan dekonstruksi Derrida, setiap masyarakat yang menghasilkan makna budaya dipercaya memiliki pusatnya masingmasing untuk menetapkan kebenaran. Sehingga sangat wajar jika antara golongan orang tua dan anak muda memiliki kepercayaan dan pemaknaan sendiri mengenai konsep atau pranata erturang sekarang.

Perubahan dalam salah satu unsur akan menimbulkan penyesuaian dari berbagai sektor lain. Perubahan pemahaman ini menimbulkan problem sosial yang melibatkan hubungan antara kelompok maupun hubungan antar individu. Akibat dari pemahaman yang berubah pada kaum muda Berastagi pada akhirnya akan menimbulkan pertentangan bagi orang-orang yang ada di dalam lingkup budaya tersebut. Perubahan pemahaman terhadap erturang pada kaum muda saat ini telah merubah kebiasaan yang telah berlangsung lama.

Mentalitas sakral semua warisan lama (tradisi, tingkah laku) sangat dipegang teguh oleh masyarakatnya sesuai dengan jamannya. Kaum tua beranggapan bahwa tradisi merupakan hal yang paling penting dibanding apapun juga. Orang tua masih percaya bahwa jika norma atau tradisi lama dilanggar, maka akan mengakibatkan atau menimbulkan marabahaya bagi masyarakat sekitarnya. Mereka percaya bahwa setiap tradisi masih memiliki nilai spiritual yang tinggi dan hal tersebut berpengaruh pada kehidupan sehari - hari pelaku. Hal ini sangat bertentangan dengan pendidikan yang diterima kaum muda dilingkungan sekolah. 
Kaum muda yang di hadapkan dengan pemikiran yang realis kemudian menjadi kurang kepercayaan terhadap warisan lama ini sehingga menimbulkan mentalitas utiliter bagi para kaum muda Berastagi.

Menurut Simandjuntak (1984:9), lenyapnya pola-pola kelakuan tradisional sekarang memang menimbulkan ketegangan. Tetapi selama pola-pola lama menghilang secara lambat kemudian diikuti oleh munculnya polapola baru secara lambat pula, proses ini tidak begitu berbahaya karena masih ada kesempatan "bernafas". Perubahan sosial dalam kehidupan kaum muda Berastagi terjadi karena mereka sedang mencari own identitynya. Pencarian jati diri tersebut dimanifestasikan kedalam penghayatan yang salah terhadap sesuatu karena lemahnya daya persepsi kaum muda.

Erturang yang merupakan salah satu bagian dari tradisi Karo dimaknai sebagai hal yang bebas dalam konteksnya, sehingga nilai kesakralan dari erturang tersebut menjadi semakin berkurang. Proses perkenalan yang sudah tidak mengikuti alur membuat makna sakral dari konteks erturang sudah mulai hilang. Erturang dimaknai ulang sebagai wujud dari komunikasi sosial yang dipahami sebagai ideologi tiap-tiap kelompok muda. Artinya budaya konsumen juga menjadi salah satu penyebab terjadinya dekonstruksi pranata erturang.

Kemampuan kaum muda Karo yang cukup mudah dan cepat beradaptasi terhadap perkembangan teknologi juga mengakibatkan peran marga dalam ertutur baik itu di dunia nyata maupun di media sosial saat ini telah mengalami kemunduran. Sadar atau tidak kaum muda saat ini lebih mementingkan kebutuhan dirinya dibandingkan mengikuti peraturan yang sudah ada sejak lama. Proses perkenalan yang lebih mengutamakan paras manjadi suatu alasan terjadinya fenomena perkawinan erturang yang terjadi pada kaum muda Karo.

Mentalitas utiliter atau sekuler menggunakan hal-hal yang sesuai dengan kebutuhan sehari-hari. Mentalitas sekuler ini merupakan penggerak perubahan sosio kultural (Simandjuntak, 1984:7). Hal ini didukung dengan pernyataan Ranggawarsita dalam Kuntowijoyo
(2006:11) yang mengatakan bahwa sekarang martabat negara tampak telah sunyi sepi, sebab rusak pelaksanaan peraturannya, karena tanpa teladan, orang meninggalkan kesopanan, para cendikiawan dan para ahli terbawa, hanyut ikut arus dalam jaman bimbang, bagaikan kehilangan tanda-tanda kehidupannya, kesengsaraan dunia karena tergenang berbagai halangan. Akibat dari bergesernya pemahaman dan perubahan aplikasi pranata erturang, tidak jarang saat ini kaum muda melakukan perkawinan dengan turangnya. Sama halnya dengan yang diungkapkan oleh Tridah Bangun (1990:46-47) bahwa dalam zaman yang sudah modern ini menurut kacamata adat Karo, sudah banyak penyimpangan perkawinan. Kamarto Sunarto (2000:182) bahwa penyimpangan merupakan perilaku yang oleh sejumlah besar orang dianggap sebagai hal yang tercela dan diluar batas toleransi. Perkawinaan semarga bagi Suku Karo merupakan suatu bentuk penyimpangan terhadap peraturan adat. Fauziah (2005:23) mengungkapkan bahwa larangan perkawinan semarga akan mengakibatkan anak-anak yang dilahirkan akan menjadi haram di mata hukum adat karena tidak adanya pengakuan dari masyarakat adat setempat Alumni walaupun menurut hukum nasional perkawinan tersebut sah.

Proses pelaksanaan perkawinan bagi kaum muda erturang memang jelas berbeda dari perkawinan ideal Suku Karo. Perkawinan semarga biasanya hanya diresmikan secara agama sedangkan proses perkawinan adat tidak atau belum dilakukan oleh pelaku. Apabila dilihat dari ketentuan agama ditambah dengan adanya pendaftaran di catatan sipil, menurut kacamata agama perkawinan tersebut sudah sah dan diakui. Namun menurut kacamata adat Karo, pernikahan seperti itu masih belum sah karena belum dilaksanakan acara "nggalariutang" man kalimbubu (menyelesaikan urusan seperti uang mahar dan lain-lain antara kedua keluarga). Oleh karena itu perkawinan dianggap belum sah. Karena dianggap belum sah, maka menurut adat Karo pasangan tersebut dianggap sebagai pasangan "kumpul kebo". Akibatnya keluarga baru ini tidak diundang untuk 
berpartisipasi pada setiap acara adat. Dengan kata lain mereka akan terkucilkan oleh adat dan lingkungan orang Karo karena dianggap bukan pasangan suami istri yang sah.

Tamboen (1952:151) mengatakan bahwa suatu perkawinan baru sah sesudah dilakukan upacara mukul, yakni pada malam yang sudah ditentukan mempelai perempuan dan laki-laki bersama-sama makan dari sebuah piring yang berisi daging ayam, nasi dan telur. Bagi kaum muda Karo yang menikahi pasangan semarganya, mereka memiliki cara- cara sendiri untuk mensahkan hubungan tersebut meskipun belum secara adat. Secara umum pasangan perkawinan pada penelitian ini merupakan masyarakat Karo yang beragama Kristen yang mayoritas merupakan jemaat gereja GBKP. GBKP sebagai salah satu gereja di Tanah Karo termasuk di Berastagi sebenarnya tidak memiliki hak untuk melarang perkawinan semarga. Namun GBKP juga memiliki Undang-undang yang berkaitan dengan pelarangan perkawinan tersebut. Undang-undang GBKP mengenai perkawinan dalam Tata Gereja GBKP edisi Sinode 2010-2015 pasal 2 ayat 5 bagian B berbunyi perkawinan kawin sumbang (semarga) yang dilarang adat, tidak dapat diberkati dalam GBKP. Ketegasan dari GBKP menjadi bentuk keselarasan antara GBKP sebagai gereja suku karo dengan adat budaya di daerah tersebut. Akibat tidak adanya restu dari pihak GBKP, kaum muda yang ingin mensahkan perkawinan mereka justru memilih gereja lain di dalam atau di luar Tanah Karo yang sama sekali tidak memiliki hubungan dengan adat Karo. Jalan lain yang ditempuh oleh pelaku adalah dengan pindah keyakinan contohnya dari Kristen menjadi Islam. Hal ini dilakukan untuk mempermudah mereka meresmikan hubungannya. Sangat disayangkan ketika seseorang mengganti keyakinannya hanya untuk mensahkan sebuah pernikahan yang salah menurut adat.

Setiap tindakan pasti memiliki konsekuensi, begitu juga dengan pernikahan semarga. Pernikahan semarga merupakan bentuk pernikahan yang sangat dilarang di Suku Karo, oleh karena itu sangat wajar bila masyarakat memberi hukuman bagi para pelakunya. Per- kawinan semarga dalam Suku Karo bukan hanya mencoreng nama baik keluarga, tetapi juga mencoreng nama baik masyarakat sekitarnya. Pada masyarakat Berastagi, hukuman yang diberikan bagi pelaku pernikahan semarga merupakan hukuman berbentuk lisan dan telah lama di pegang masyarakat Suku Karo di Berastagi. Namun pada saat ini hukuman berbentuk kekerasan fisik yaitu dibunuh dan dikucilkan sudah tidak digunakan lagi.Ini terjadi karena masyarakat sudah mengenal hukum negara yang melarang kekerasan fisik.Selain itu masyarakat juga sudah mendapatkan pengetahuan dari baik secara formal maupun informal dan juga dipengaruhi oleh perkembangan teknologi sehingga hukuman fisik untuk sekarang ini sudah tidak dilakukan lagi. Meski demikian, kekerasan psikis menjadi bentuk kekerasan yang paling dominan saat ini.

Perkawinan semarga sejak dulu telah dilarang oleh adat karena dianggap dapat merusak peranan tutur dan tata cara adat bagi pelaku itu sendiri sehingga menurut adat setiap pelanggarnya perlu diberlakukan hukuman sosial. Pasangan perkawinan semarga dapat dikatakan tidak memiliki tegun lagi karena memiliki marga yang sama. Jika mengikuti konsep Suku Karo dalam tiap kegiatan adat, mereka tidak memiliki tempat karena setiap orang dengan tegun yang berbeda-beda memiliki tanggungan yang berbeda pula. Oleh karenanya mereka tidak mendapat tempat dalam adat karena pasangan tersebut tidak dapat diputuskan harus menjadi anak beru atau $k a-$ limbubu atau sukut sekalipun.

Hasibuan (2010:130-131) mengatakan bahwa sebenarnya dalam hukum adat terdapat konformitas bagi perkawinan semarga tersebut. Hukuman bagi perkawinan semarga dapat dihapuskan jika pelaku tersebut mampu membayar utang adat untuk menghapuskan hukuman adatnya. Dengan membayar utang adat menjadi bentuk pluralisme yang diberikan oleh adat. Dengan kata lain hukum adat yang cenderung dominan telah berubah karena adanya adaptasi dengan keadaan saat ini. Masyarakat Berastagi memberlakukan proses konformitas hukum adat bagi para pelaku perkawinan se- 
darah dengan melakukan acara pembayaran utang adat. Utang adat yang dimaksud adalah dengan mengganti beru atau marga istri menjadi marga lain yang berbeda dari marga suami. Menurut Efiatti (2007) wanita yang kawin semarga harus merombak marganya dengan meminta marga dari ibu si suami melalui proses adat. Marga ibu yang diberikan kepada istri hanya berlaku bagi dirinya sendiri. Setelah penetapan marga tersebut, maka si istri akan menjadi kelompok marga ibu dari suami dan bukan lagi kelompok marga orang tua kandungnya. Proses ini yang disebut dengan membayar utang adat dalam perkawinan semarga.

Menurut Ginting (1997:40) proses pembayaran utang adat tersebut akan diikuti dengan menikahkan pelaku secara adat. Namun pernikahan tersebut berbeda dengan pernikahan biasanya.Pernikahan tersebut disebut dengan ngeranaken. Adanya pernikahan ini karena perlu untuk dibicarakan sebab tidak sesuai dengan perkawinan ideal menurut adat Karo. Namun para pelaku perkawinan yang ada di Berastagi saat ini belum melakukan proses pembayaran utang adat tersebut. Tindakan pelaku yang tidak melakukan acara pembayaran utang adat disebabkan oleh ketakutan dan rasa malu yang masih dirasakan oleh pelaku. Selain itu, faktor ekonomi juga menjadi kendala berangsungnya acara ini mengingat selama proses berlangsungnya acara ini seluruhnya menjadi tanggung jawab pelaku. Akibatnya, hingga saat ini para pelaku tidak diikutsertakannya pada tiap-tiap acara adat. Dapat disimpulkan bahwa pernikahan semarga memang memberikan dampak jangka panjang bagi pelakunya khususnya dalam kegiatan adat. Pelaku akan menjadi orang Karo yang tidak dianggap karena belum melaksakan ketetapan adat.

\section{SIMPULAN}

Erturang sebagai sebuah struktur mengalami perubahan yang signifikan. Dari perubahan tersebut dapat ketahui bahwa pranata erturang telah mengalami proses dekonstruksi. Ada dua bentuk dekonstruksi yang dapat dilihat dari bagaimana kaum muda Berastagi mengapikasikan pranata tersebut dalam kesehariannya. Bentuk dekonstuksi tersebut adalah berubahnya pranata erturang dari kaku atau pantang menjadi bebas dan dari sakral (utama) menjadi utiliter (sekunder).

Terjadinya perkawinan semarga disebabkan oleh beberapa dua faktor yaitu faktor internal dan faktor eksternal.Faktor internal adalah karena keinginan mereka sendiri yang didasari dengan ikatan yang kuat antara pasangan tersebut, selain itu tingginya tingkat rasa nyaman antara keduanya juga mengakibatkan pasangan ini sulit untuk dipisahkan. Komunikasi yang intens dan seringnya pelaku bertukar fikiran juga menjadi pendukung terjadinya perkawinan semarga. Faktor eksternal yang melatarbelakangi perkawinan semarga adalah adanya penggunaan media sosial yang salah sehingga menimbulkan salah sangka antara keduanya. Marga yang sengaja tidak disisipkan dalam akun online membuat mereka tidak sadar kalau mereka telaah berhubungan dengan semarganya. Di samping itu kecemburuan sosial yang dirasakan pelaku terhadap hak istimewa yang diperoleh oleh beberapa marga Karo juga menjadi faktor maraknya perkawinan semarga pada saat ini.pelaku merasa adat memperlakukan mereka dengan tidak seimbang sehingga mereka melakukan perkawinan semarga untuk menunjukkan eksistensi mereka sebagai bagian dari marga Karo.

Implikasi yang didapat dari perkawinan semarga terdiri dari dua bentuk implikasi yaitu implikasi pada kehidupan beradat dan implikasi pada kehidupan bermasyarakat. Dalam kehidupan adat, pelaku tidak lagi mendapat tempat sebelum mereka mengesahkan pernikahan secara adat. Selain itu pelaku juga kehilangan hak-haknya sebagai warga masyarakat Karo. Dengan kata lain mereka tidak bisa melakukan perkawinan secara ideal sesuai perkawinan Karo yang sah, dan dianggap bukan lagi bagian dari Suku Karo. Implikasi dalam kehidupan bermasyarakat yang dialami pelaku adalah mereka merasa malu dan takut untuk bersosialisasi karna mereka dianggap pasangan "kumpul kebo". Selain itu 
mereka sering dijadikan bahan gossip oleh lingkungannya sehingga menurunkan rasa percaya diri pelaku.

\section{UCAPAN TERIMA KASIH}

Ucapan terima kasih kami sampaikan kepda berbagai pihak yang telah membantu dalam melakukan penelitian ini. Ucapan terima kasih juga sampaikan kepada dewan redaksi Jurnal Socia yang telah menerima dan melakukan review untuk penyempurnaan artikel.

\section{DAFTAR PUSTAKA}

Al-Fayyadl, Muhammad. 2006, Derrida, Yogyakarta: Lkis Bangun, Tridah. 1986, Manusia Batak Karo, Jakarta: Inti Indayu

Barus, U.C dan Sembiring, Mberguh. 1993, Sejumput Adat Budaya Karo, Kabanjahe: Abdi Karya

Cavallaro, Dani. 2004, Critical and Cultural Theory: Teori Kritis dan Teori Budaya, Yogyakarta: Niagara

Darwan, Prinst. 2008, Adat Karo, Medan: Bina Media Perintis Geertz, Clifford. 1992, Tafsir Kebudayaan, Yogyakarta: Pt. Kanisius

Gintingsuka, Sadakata. 1997, Ranan Adat "Orat Ngeluh-Rikut Kiniteken Kalak Karo",Jakarta: Yayasan MergaSilima

Hasibuan, Effiati Juliana dan Harahap, Hottop. 2007, "Pluralisme Hukum pada Kasus Perkawinan Semarga pada Etnis Padang Lawas di Kabupaten Tapanuli Selatan", Jurnal Harmoni, Volume 1, Nomor 3, Mei, hlm.127-131

Kuntowijoyo. 2006, Budaya dan Masyarakat, Yogyakarta: Tiara Wacana

Moleong, Lexi J. 2007, Metodologi Penelitian Kualitatif, Bandung: Pt. Remaja Rosdakarya Offset

Narwoko, J. Dwi dan Susanto, Bagong. 2011, So- siologi: Teks Pengantar dan Terapan, Jakarta: Kencana

Pitana, Titis.S. 2010,“Dekonstruksi Makna Simbolik Arsitektur Keraton Surakarta” (Desertasi), Denpasar: Program Pascasarjana Universitas Udayana

Ratna, Nyoman Kutha. 2010, Metodologi Penelitian Kajian Budaya dan Ilmu Sosial Humaniora pada Umumnya, Yogyakarta: Pustaka Pelajar

Ritzel, George dan Goodman, Douglas J. 2004, Teori Sosiologi Modern, Jakarta: Prenanda Media

Sembiring, Fauziah Astuti. 2005, "Perkawinan Semarga dalam Klan Sembiring pada Masyarakat karo di Kelurahan tiga Binanga, Kecamatan Tiga Binanga, Kabupaten Karo", (Tesis), Universitas Diponegoro. Semarang Simandjuntak, B. 1984, Latar Belakang Kenakalan Remaja, Bandung: Alumni Sitepu, Sempa, dkk. 1996, Pilar Budaya Karo, Medan: Bali Scan

Sugiyono. 2007, Metode Penelitian Kuantitatif Kualitatif dan R\&D, Bandung: Alfabeta

Sunarto, Kamanto. 2000, Pengantar Sosiologi, Jakarta: Lembaga Penerbit Fakultas Ekonomi Universitas Indonesia

Sutopo, HB. 2002, Metode Penelitian Kualitatif, Surakarta: Sebelas Maret University Press Tamboen, P. 1952, Adat Istiadat Karo,Jakarta: Balai Pustaka

Tarigan, Sarjani. 2011, Kepercayaan Orang Karo Tempo Doeloe, Medan: BNB-Balai Adat Budaya Karo Indonesia

Tarwodjo. 1994, Etnografi Suatu Tantangan Penelitian Kualitatif, Jakarta: Balai Pustaka Weber, Max. 2013, Teori Dasar Analisis Kebudayaan, Yogyakarta: IRCiSoD 